\title{
IMPLIKASI PROGRAM BAHTS AL-MASÂIL TERHADAP NALAR KRITIS SANTRI DI PONDOK PESANTREN GEDANGAN DALEMAN KEDUNGDUNG SAMPANG
}

\author{
Muqoffi \\ STAI Nazhatut Thullab Sampang \\ Email : muqoffi@gmail.com
}

\begin{abstract}
Abstrak:
Kurikulum pemerintah yang diselenggarakan di Sekolah/Madrasah perlu disempurnakan dengan program bahts al-masâil, sebuah diskusi ilmiyah yang dominan di Pondok Pesantren dalam rangka menjawab beragam persoalan masyarakat terkini sekaligus sebagai media obyektif dalam menumbuhkan nalar kritis terhadap diri santri. Karenanya, penulis merasa penting melakukan penelitian tentang program bahts al-masâil di Pondok Pesantren Gedangan Daleman Kedungdung Sampang dengan fokus terhadap prosedur dan mekanisme pelaksanaannya, baik di tingkat MI, MTs, MA dan Guru serta implikasinya terhadap nalar kritis santri. Dalam penelitian ini menggunakan metode kualitatif deskriftif dan hasil penelitiannya menjelaskan bahwa santri benar-benar punya nalar kritis dalam program bahts al-masâil tersebut dalam merespon jawaban dan penjelasan, mengkaji setiap referensi, menganalisa soal dan hasil keputusan, sehingga budaya kritis ini memberi dampak terhadap terciptanya mindset berpikir kritis di luar forum, baik berkaitan dengan kajian keilmuan maupun realitas kehidupan.
\end{abstract}

Kata Kunci: Bahts al-Masâil, Nalar Kritis

\section{Pendahuluan}

Materi Pendidikan Agama Islam (PAI) yang diprogramkan di Sekolah/Madrasah berstandart nasional tidak memuat pembahasan hukum Islam secara komprehensif, masih banyak bahasan yang disajikan secara parsial, baik yang berkenaan dengan ubûdiyah, munâkahah, mu'âmalah dan persoalan urgen lainnya, sehingga khazanah keilmuan yang didapat tidak mampu menjawab dinamika kehidupan yang dihadapi oleh peserta didik, baik masalah internal maupun eksternal, termasuk sosio-kultural dan sosio-religius yang terus berkembang di masyarakat sejalan dengan perkembangan zaman.

Pembahasan yang tidak komprehensif tersebut penulis temukan di beberapa buku yang dikeluarkan oleh Kementerian Agama. Diantaranya dapat penulis contohkan 1. Dalam masalah memandikan mayat, hanya dijelaskan tentang mayat yang mati dalam kondisi tubuh normal. ${ }^{1}$ Sedangkan mayat yang kondisi tubuh tidak normal perlu penanganan khusus, seperti mayat yang darahnya mengalir terus-menerus, tubuhnya hancur berserakan dan jasad yang terbakar sehingga tidak dapat dimandikan dengan air, 2. Dalam masalah hak dan kewajiban suami-

\footnotetext{
${ }^{1}$ Kementerian Agama, Fikih Pendekatan Saintifik Kurikulum 2013 Madrasah Aliyah Kelas X (Jakarta: Kementerian Agama, 2015), 24-25.
} 
istri disebutkan sangat simple. Mengenai kewajiban suami hanya disebutkan memberi nafkah dan mendidik keluarga. ${ }^{2}$ Sedangkan rincian dari kewajiban ini sangat beragam, mulai dari kadar nafkahnya, kewajiban suami mengajari istri, materi yang wajib diajarkannya dan sanksi-sanksi yang bisa digunakan dalam menyikapi pelanggaran istri.

Dalam al-Qur'an, Allah Swt. berfirman:

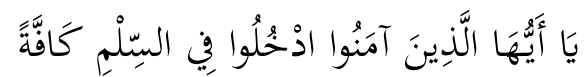

Artinya: wahai orang-orang yang beriman, masuklah kalian pada Islam secara keseluruhan. ${ }^{3}$

Untuk bisa dikategorikan masuk Islam secara keseluruhan sesuai dengan tuntunan al-Qur'an, maka peserta didik wajib memahami dan menguasai Pendidikan Agama Islam (PAI) secara menyeluruh, khususnya bidang pelajaran yang fardha 'ain. Bahkan, ulama memvonis hukum haram dan dosa besar bagi peserta didik yang mengenyam pendidikan di sekolah umum sehingga bidang pelajaran yang fardha 'ain menjadi terbengkalai. ${ }^{4}$ Jadi, tidak boleh belajar materi MTK, IPA dan Bahasa Indonesia, apabila dengan begitu peserta didik tidak paham cara mandi besar dan praktik yang benar tentang shalat dan wudhu'.

Oleh karena itu, agar peserta didik dapat melaksanakan kewajiban belajarnya dengan baik, maka lembaga pendidikan Islam harus bisa menciptakan inovasi dan renovasi sistem pendidikan dengan tepat. Tidak hanya terpaku pada sistem pendidikan nasional, tapi harus menambah program pendidikan yang difokuskan pada pendalaman ilmu agama. Pengurus lembaga memiliki banyak alternatif kegiatan yang dapat menanggulangi minimnya kapasitas keilmuan peserta didik di bidang ilmu agama, seperti memprogramkan Madrasah Diniyah (MADIN) seperti yang banyak direalisasikan di Madrasah-Madrasah swasta, mengadakan ekstra kuriluler yang bermaterikan ilmu agama, seperti praktik tata cara shalat, pembekalan tentang ilmu haid, nifas, istihâdhah dan wilâdah, dan yang paling pokok adalah pengajian al-Qur'an.

Inovasi pendidikan tersebut harus menjadi tanggungjawab semua lembaga pendidikan Islam, khususnya Pondok Pesantren. Pengkhususan ini melihat misimisi Pondok Pesantren yang menjadi pedoman dalam merealisasikan programprogramnya. Menurut Mohammad Tidjani Djauhari, Pondok Pesantren memiliki 2 misi, sebagai berikut:

1. Pondok Pesantren sebagai pendidikan ummat secara umum. Pada bidang ini, tugas Pesantren adalah mendidik dan menyiapkan pemuda-pemudi Islam untuk menjadi ummat berkualitas dalam berbagai bidang dan bukan saja mampu mengintaskan mereka dari jurang kebodohan dan keterbelakangan, tapi juga mampu melaksanakan misi amar makruf nahi munkar.

2. Pondok Pesantren sebagai lembaga pendidikan pengkaderan ulama agent of excellence dan pengembangan ilmu pengetahuan khususnya ilmu agama. Dalam hal ini, tugas Pesantren adalah mendidik dan menyiapkan thâifah

\footnotetext{
2 Kementerian Agama, Fikih Pendekatan Saintifik Kurikulum 2013 Madrasah Aliyah Kelas XI (Jakarta: Kementerian Agama, 2015), 97-98.

${ }^{3}$ QS. al-Baqarah: 208.

4 Tim Kajian Fikih Pondok Pesantren Sidogiri, Santri Salaf Menjawab 2 (Pasuruan: Pustaka Sidogiri Pondok Pesantren Sidogiri, 1437H.), 951.
} 
mutafaqqihah fî al-dîn, yaitu kader-kader ulama pengasuh Pesantren yang mampu mewarisi sifat dan kepribadian para Nabi serta siap melaksanakan tugas indzâr al-Qaum. ${ }^{5}$

Pondok $^{6}$ Pesantren ${ }^{7}$ Gedangan Daleman Kedungdung Sampang adalah salah satu lembaga pendidikan yang berupaya dan berusaha untuk mewujudkan misimisi ini, dengan berbagai program yang dikonsentrasikan kepada penguasaan isi kitab kuning yang notabene adalah rujukan utama ilmu agama. Salah satu program itu adalah bahts al-masâil, sebuah diskusi ilmiah yang dijadwalkan sebulan dua kali pada malam Selasa atau malam Kamisdengan durasi 2-3 jam, dimulai jam 20.00 Istiwak sampai selesai, dan menjadi salah satukegiatan wajib yang harus diikuti olehsemua santri Pondok Pesantren Gedangan Daleman Kedungdung Sampang, baik yang mukim maupun yang tidak.

Ada beberapa poin penting yang berhubungan dengan pelaksanaan bahts almasâil di Pondok Pesantren Gedangan. Diantara poin-poin itu adalahsebagai berikut:

1. Bahts al-masâil dilaksanakan secara berjenjang, mulai dari tingkat MI, MTs, MA dan guru. Dalam tingkat MI, diikuti oleh santri kelas 5-6, MTs diikuti oleh santri kelas 1-3, MA diikuti oleh santri kelas 1-3, dan tingkat guru diikuti oleh semua asâtidz (bukan asâtidzah), baik yang berdomisili di area Pondok atau yang bukan. Setiap jenjang memiliki mekanisme berbeda yang didesain secara proporsional dan profesional sesuai dengan potensi peserta.

2. Tidak semua peserta di setiap jenjang mampu menjawab persoalan hukum yang diangkat dalam forum bahts al-masâil. Berbeda dengan peserta bahts almasâil setingkat Nahdlatul Ulama (NU) yang lazimnya semua peserta memiliki kemampuan cukup dan mumpuni, karena memang peserta yang diikut sertakan adalah kiai atau ustadz pilihan, sedangkan dalam Pondok Pesantren ini, diikuti oleh semua santri yang tentunya tingkat kemampuannya beragam. Karenanya, realisasinya harus memiliki cara yang taktis dan efektif, tidak membiarkan diam tanpa pendapat dan kontribusi apapun terhadap santri yang berpengetahuan rendah.

3. Bahts al-masâil adalah bagian ekstra kurikuler Pondok Pesantren yang tidak menentukan pada kenaikan kelas dalam pendidikan Madrasah dan tidak menjadi syaratkelulusan, tapi antusiasme santri dalam mengikuti program ini cukup tinggi.Bahkan menjadi pemicu mereka untuk menambah koleksi perpustakaan pribadi sekaligus meningkatkan partisipasinya pada perpusatakaan Pondok Pesantren. Tidak hanya mempelajari referensi yang digunakan di Madrasah atau forum yang lain.

4. Peserta yang dinilai memiliki prestasi gemilang dalam pelaksanaan bahts almasâil tidak mendapat penghargaan resmi dari lembaga layaknya pendidikan klasikal, namun konsistensi mereka tetap terjaga dengan baik dalam menjawab

\footnotetext{
${ }^{5}$ Mohammad Tidjani Djauhari, Masa Depan Pesantren, Agenda yang Belum Terselesaikan (Jakarta: Taj Publishing, 2008), 86.

${ }^{6}$ Pondok: wadah pengemblengan, pembinaan dan pendidikan serta pengajaran ilmu pengetahuan. (Bahri Ghazali, Pesantren Berwawasan Lingkungan (Jakarta: CV. Prasasti, 2002), 20.

${ }^{7}$ Pesantren: sebuah institusi yang befungsi mendidik santri atau mendidik orang agar menjadi santri (Djauhari, Masa Depan, 85).
} 
pertanyaan yang diajukan dan meluruskan jawaban-jawaban peserta lain yang kurang tepat.

5. Pelaksanaan bahts al-masâil di lembaga ini tidak hanya berguna untuk mempertajam nalar kritis santri secara pribadi tapi juga bermanfaat memecahkan problematika hukum yang dihadapi masyarakat umum melalui forum bahts al-masâil yang dilaksanakan di lembaga ini, atau mendelegasikan mereka dalam forum bahts al-masâil di tempat lain, seperti bahts al-masâil SeMadura, antar Pondok Pesantren, bahts al-masâil NU tingkat Kabupaten, tingkat Kecamatan dan lain sebagainya.

Melihat data dan fakta ini, peneliti merasa perlu mengadakan penelitian lebih dalam mengenai nalar kritis santri Pondok Pesantren Gedangan melalui program bahts al-masâil. Banyak hal yang perlu dikaji secara intensif dan akurat, seperti prosedur dalam menetapkan topik bahasan di setiap jenjang yang kapasitas kemampuannya berbeda, teknik yang diberlakukan untuk meningkatkan kualitas diskusi pada semua peserta, cara-cara khusus untuk menggerakkan semangat peserta, wujud nalar kritis santri pada saat mengikuti bahts al-masâil dan di luar forum, dan hal-hal lain yang memiliki relevansi dengan pembahasan.

\section{Metode Penelitian}

Pendekatan yang digunakan dalam penelitian ini adalah penelitian kualitatif. Penelitian kualitatif adalah metodologi penelitian yang menghasilkan data deskriptif berupa kata-kata tertulis atau lisan dari orang-orang dan perilaku yang dapat diamati. ${ }^{8}$ Penelitian ini dilakukan di Pondok Pesantren Kp. Gedangan Ds. Daleman Kec. Kedungdung Kab. Sampang. Lokasi yang peneliti pilih ini adalah lembaga pendidikan Islam yang perkembangannya cukup pesat.

Untuk mendapatkan data penelitian sesuai yang diharapkan, peneliti melakukan observasi, wawancara dan dokumentasi. Observasi adalah metode penelitian dengan dengan menggunakan salah satu panca indra, yaitu indra penglihatan dengan mengamati informasi yang akan diambil berupa kondisi dan fakta alami, tingkah laku dan hasil kerja subjek penelitian dalam situasi yang alami. ${ }^{9}$ Wawancara adalah metode penelitian di mana peneliti berhadapan langsung dengan subjek yang diteliti. Ada beberapa pihak yang peneliti wawancarai, yaitu 1. KH. Abd. Wahhab, Kabag Ma'hadiyah, 2. Ust. H. Abd. Qohar, Kabag Ta'limiyah, 3. Ust. Hoiruddin, Ketua Musyawarah Guru, Ust. Hisbullah Ketua Musyawarah MA, Ust. Muzakky, S.Pd. Ketua Musyawarah MTs dan ust. Rafiuddin, Ketua Musyawarah MI. Adapun teknik pengumpulan data berupa dokumentasi, peneliti lakukan dengan mendokumentasi seluruh kegiatan bahts al-masâil di semua tingkatan, hasil keputusan bahts al-masâil, laporan perkembangan santri peserta bahts al-masâil dari ketua bahts al-masâil, pedoman kerja yang dibuat oleh Kabag Ta'limiyah dan berbagai hal dari Kabag Ma'hadiyah.

\section{Program Bahts Al-Masâil Di Pondok Pesantren Gedangan}

Bahts al-masâil merupakan kata majemuk yng berasal dari dua kata, yaitu bahts yang berarti pembahasan dan al-masâil (bentuk jamak dari masalah) yang

\footnotetext{
8 Basrowi \& Suwandi, Memahami Penelitian Kualitatif (Jakarta: Rineka Cipta, 2008), 20.

${ }^{9}$ Sukardi, Metodologi Penelitian Pendidikan (Jakarta: BumiAksara, 2013), 78.
} 
berarti masalah-masalah. Dengan demikian bahtsal-masâil secara harfiyah mempunyai arti pembahasan masalah-masalah. ${ }^{10}$ Masalah-masalah yang dibahas dalam forum bahts al-masâil adalah berbagai macam disiplin ilmu pendidikan yang diorientasikan sebagai jawaban atas problematika hukum yang dihadapi masyarakat atau sekedar mencari kejelasan makna dari materi pendidikan yang ditemuinya. Bahts al-masâil bisa juga disebut musyawarah atau diskusi. Diskusi menurut bahasa adalah tukar pikiran antara dua orang atau lebih untuk menyelesaikan suatu persoalan. Menurut istilah, diskusi adalah tukar menukar informasi, pendapat dan unsur-unsur pengalaman secara teratur dengan maksud untuk mendapat pengertian bersama yang lebih jelas dan lebih teliti tentang sesuatu atau untuk mempersiapkan dan merampungkan keputusan bersama. ${ }^{11}$

Dalam al-Qur'an, Allah Swt. berfirman:

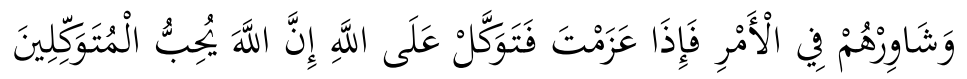

Artinya: dan bermusyawarahlah dengan mereka dalam urusan itu. Kemudian, apabila kamu telah membulatkan tekad, maka bertawakkallah kepada Allah. Sesungguhnya Allah menyukai orang-orang yang bertawakkal. ${ }^{12}$

Di Pondok Pesantren Gedangan program bahts al-masâil dilaksanakan 1 kali dalam seminggu dengan managemen yang berbeda sesuai dengan tingkatan. Peneliti dapat gambarkan sebagai berikut:

1. Tingkat MI

Program bahts al-masâil di tingkat MI hanya dikonsentrasikan membahas ulang kitab pelajaran Madrasah yang kontennya adalah masalah agama, seperti Fiqih dan Tauhid. Ketua menjadwalkan peserta untuk membaca kata dan pengertiannya kemudian menjelaskan isinya. Sementara peserta lain diberi kesempatan untuk bertanya dan mengkritisi. Mengkritisi bacaannya terkait dengan kaidah Nahwu-Sharraf atau pemahaman isinya. Ketua memilih materi pembahasan yang sejalan dengan kapasitas kemampuan peserta.

2. Tingkat MTs

Program bahts al-masâil di tingkat MTs menggunakan dua sistem, yaitu 1. Membaca kitab Fathu al-Qarǐb dengan cara yang sama dengan tingkat MI, 2. Mendiskusikan persoalan hukum fiqih dengan tema yang mudah dijangkau oleh santri. Tema pembahasan disiapkan oleh ketua yang jawabannya sudah ada di 2 kitab, Fathu al-Qarǐb dan Fathu al-Muǐn. Ketua pun menginformasikan kepada santri untuk mencari di 2 kitab tersebut. Tapi tidak menutup ruang bagi santri yang ingin mengembangkan jawaban lebih jauh dari kitab lain yang mu'tabarah. Di tingkat MTs, moderator sudah mulai diperankan kepada santri MTs yang dilihat cukup kompeten di bidang itu sekaligus sebagai proses pembelajaran.

3. Tingkat MA

Program bahts al-masâil di tingkat MA menggunakan dua sistem, yaitu 1. Membaca kitab Fathu al-Muin dan mendiskusikannya. Diskusi difokuskan kepada pengertian dari kitab yang dibaca. Tidak lagi mengkritisi Nahwu-

${ }^{10}$ M. Ridlwan Qoyyum Sa'id, Rahasia Sukses Fuqoha (Kediri :MitraGayatri, 2006), 60.

${ }^{11}$ Syahraini Tambak, 6 Metode Komunikatif Pendidikan Agama Islam (Yogyakarta: Graha Ilmu, 2014), 198-199.

12 QS. Ali Imran: 159. 
Sharrafnya. Boleh disandingkan dengan kitab lain dengan tema yang sama dalam rangka mempertajam jawaban 2. Mendiskusikan persoalan hukum dengan tema kekinian, baik seputar Akidah, Fiqih, Ushul dan persoalan urgen lainnya. Diskusi tidak lagi terbatas kepada persoalan hukum fiqih tapi mengangkat semua konten kekinian, khususnya persoalan yang menjadi polemik di masyarakat umum atau disalahtafsirkan oleh oknum tertentu. Untuk moderator sepenuhnya diperankan oleh santri MA. Program bahts almasâil di tingkat MA dikembangkan dengan sistem penulisan karya ilmiyah. Setelah diskusi ilmiyah menghasilkan kompilasi hukum yang benar dan disepakati bersama oleh Mushahhih dan semua peserta, maka ketua menugaskan salah satu dari mereka untuk didokumentasi dalam bentuk artikel dengan memuat: judul, nama penulis, asal madrasah, pendahuluan dan isi. Setiap kutipan harus disertai footnote beserta semua ta'bir versi Arabnya.

4. Tingkat Guru

Program bahts al-masâil di tingkat Guru menggunakan banyak sistem. Diantaranya, 1. Membaca dan membahas materi pelajaran santri yang digunakan di Madrasah untuk mempersiapkan kemampuan guru sebelum mengajar di kelas, 2. Membaca ulang hasil keputusan bahts al-masâil NU (Nahdlatul Ulama) yang dimuat dalam buku Ahkâm al-Fuqahâ, 3. Mendiskusikan berbagai masalah kekinian yang ditemukan oleh para guru.

Diskusi ilmiyah berupa bahtsal-masâil membutuhkan kitab kuning sebagai rujukan dalam menjawab, menentang dan memutuskan sebuah kasus. Untuk menemukan hasil keputusan hukum yang benar dan tepat, kitab yang dapat dijadikan rujukan haruslah mengacu pada satandar mutu yang disepakati, yaitu alkutub al-mu'tabarah. Al-kutub al-mu'tabarah ini dibatasi pada kitab-kitab 'ala alMadzâhib al-'Arba'ah; kitab-kitab 4 madzhab (Syafi'i, Maliki, Hanafi, Hanbali). ${ }^{13}$ Sebenarnya imam-imam madzhab yang selevel dengan imam 4 itu sangat banyak. Diantaranya adalah Sufyan al-Tsauri, Sufyan 'Uyainah, Ishaq Rahawaih dan Dawud al-Dzahiri. Hanya saja karena tidak mempunyai pengikut yang setia dalam mengembangkan madzhab mereka dan tidak banyak literatur memuat pemikiran mereka, maka mata rantai pemikiran mereka menjadi terputus. ${ }^{14}$

Di Pondok Pesantren Gedangan pada lazimnya hanya menggunakan kitab mu'tabarah Syâfiiyyah sebagaimana umumnya Pondok Pesantren di Indonesia. Kitab-kitab mu'tabarah yang lain digunakan dalam kondisi tertentu dan proporsional. Istinbât hukum yang digunakan hanya merujuk kepada metode qauly. Kecuali tidak tercover dengan metode qauly, maka menggunakan metode ilhâqy. Metode qauly adalah cara pengambilan keputusan dengan merujuk langsung pada teks kitab-kitab imam madzhab ataupun kitab-kitab yang disusun para pengikut madzhab empat (Syafi'i, Maliki, Hanafi, Hanbali). Metode ilhâqy adalah cara pengambilan keputusan dengan menyamakan masalah baru yang belum ditemukan kedudukan hukumnya terhadap masalah lama yang mirip dan telah ada keputusan hukumnya. ${ }^{15}$ Belum sampai pada taraf metode manhajy di

13 Tim Lajnah Ta'lif wa al-Nasyr, Ahkamul Fuqaha, Solusi Problematika Aktual Hukum Islam, Keputusan Muktamar, Munas, dan Konbes NU (1926-2010) (Surabaya: Khalizta, 2011), 386-387.

14 Saifullah Ma'shum dalam Ahmad Zahro, Lanjah Bahtsul Masail 1926-1999, Tradisi Intelektual NU (Yogyakarta: PT. LKiS, 2004), 81-82.

15 Ibid., 167-168 
semua tingkatan, baik tingkat MI, MTs, MA maupun Guru. Metode manhajy adalah cara pengambilan keputusan dengan menelusuri dan mengikuti metode penggalian hukum yang ditempuh oleh madzhab empat.

Program bahts al-masâil di Pondok Pesantren Gedangan diikuti oleh beberapa anggota, yaitu moderator, mushahih dan peserta. Dalam menjalankan perannya, mereka harus mengacu pada mekanisme yang sudah ditentukan, sebagaimana berikut:

1. Moderator

Moderator adalah salah satu penentu baik tidaknya perjalanan bahts almasâil. Karena itu, dia memiliki tugas yang harus dijankan dengan baik dan larangan yang harus dihindari, agar forum dapat terlaksana dengan efektif dan optimal. Tugas-tugas moderator adalah:

a. Menjaga ketertiban, mengatur dan membagi waktu

b. Memberi idzin, menerima usul dan pendapat Musyawirin.

c. Meminta nara sumber untuk menjelaskan dan menggambarkan masalah sesuai permintaan peserta.

d. Menunjuk peserta untuk menjawab masalah

e. Meminta kepada penjawab untuk membacakan ta'bir dan menerangkan kesimpulannya.

f. Meminta peserta yang pendapatnya tidak sama untuk menanggapi pendapat lain dengan mencari kelemahan jawaban dan kelemahan ta'birnya.

g. Meluruskan pembicaraan yang menyimpang dari pembicaraan.

h. Membaca kesimpulan jawaban yang telah disepakati oleh tim perumus, untuk kemudian ditawarkan kembali pada para peserta.

i. Mengetuk tiga kali bila masalah dianggap selesai dan memohon kepada Mushahih untuk memimpin pembacaan al-Fatihah bersama sebagai simbol pengesahan.

Selain tugas-tugas, moderator memiliki larangan-larangan yang tidak boleh dilanggar. Langaran-larangan itu adalah ikut berpendapat, memihak atau tidak obyektif dan mengintimidasi peserta.

2. Tim Mushahih

Tim mushahih juga harus mampu menjalankan tugasnya dengan baik. Tugas-tugas mushahih adalah:

a. Mengikuti jalannya acara bahtsal-masâil.

b. Memberikan pengarahan dan nasehat kepada peserta.

c. Mempertimbangkan dan mentasheh keputusan bahtsal-masâil dengan bacaan al-Fâtihah.

Adapun larangan-larangan mushahih yang tidak boleh dilanggar adalah:

a. Membaca al-Fâihah sebelum ada kesepakatan.

b. Pulang sebelum waktunya alias bolos, kecuali ada udzur.

3. Peserta

Peserta bahts al-masâil harus bisa bertindak sesuai dengan tugas-tugas tertentu. Tugas-tugas peserta tersebut adalah sebagai berikut:

a. Menempati arena yang tersedia sepuluh menit sebelum acara dimulai.

b. Membubuhkan tanda tangan hadir pada buku daftar yang telah disediakan. 
c. Menjawab masalah dan menyampaikan ta'birnya setelah diberi waktu oleh moderator.

d. Berbicara (menjawab masalah dan menyampaikan ta'birnya) setelah diberi waktu oleh moderator.

e. Menghormati dan menghargai peserta lain.

Larangan-larangan bagi peserta bahts al-masâil adalah sebagai berikut:

a. Keluar dari forum bahts al-masâil tanpa seidzin moderator.

b. Membuat gaduh dalam forum bahts al-masâil.

c. Berselisih pendapat dengan teman sedelegasi

d. Berbicara tanpa melalui moderator atau "debat kusir".

4. Sekretaris

Sekretaris juga punya tugas yang penting di forum bahts al-masâil, diantaranya adalah:

a. Menulis semua perlengkapan forum, mulai soal pembahasan, peserta, undangan delegasi dan lain sebagainya.

b. Mendokumentasi hasil keputusan forum dengan format yang tepat dan baik.

c. Menggandakan buku kumpulan keputusan bahts al-masâil untuk dibagikan ke peserta

Di lembaga lain termasuk di lembaga bahts al-masâil NU, dilengkapi dengan perumus dengan tugas sebagai berikut:

a. Mengikuti jalannya acara bahts al-masâil.

b. Meneliti jawaban-jawaban dan ta'bir yang masuk.

c. Memilih ta'bir yang masuk sesuai permasalahan yang dibahas.

d. Meluruskan jawaban yang dianggap menyimpang.

e. Memberikan rumusan jawaban dan ta'bir pendukung.

Sedangkan larangan-larangan perumus adalah sebagaimana berikut:

a. Memaksakan jawaban tanpa ada ta'bir dari peserta.

b. Berbicara sebelum ditunjuk moderator.

c. Berbicara diluar materi pembahasan.

d. Mengganggu konsentrasi peserta, seperti tidur, guyonan atau bersikap emosional.

e. Pulang sebelum waktunya tanpa seizin moderator

\section{Implikasi Program Bahts Al-Masâil Terhadap Nalar Kritis Santri Pondok Pesantren Gedangan}

Program bahts al-masâil di Pondok Pesantren Gedangan memberi implikasi nalar kritis yang jelas kepada santri peserta program tersebut, baik ketika mengikuti forum itu atau kajian yang lain. Secara fitri setiap manusia memiliki kemampuan untuk melakukan nalar berpikir dan sekaligus merupakan karunia besar dan spesial dari Allah Swt.

Kata Khalimi:

"salah satu ciri yang membedakan manusia dan hewan terletak pada potensi nalar (nâthiq), kegiatan nalar, atau kegiatan berpikir dalam merenungkan objek pikir. Eksistensi dan fungsionalisasi akal dapat meningkatkan derajat dan status keberdaan manusia dalam menjalankan tugas sebagai pemegang 
amanat "ibâdah", "risâlah" dan "khilâfah" di muka bumi ini. ${ }^{16}$ Berpikir merupakan kegiatan akal untuk mengolah pengetahuan yang telah kita terima melalui panca indera dan ditunjukkan untuk mencapai suatu kebenaran. Menurut Plato, Aristoteles, berpikir adalah bicara dengan dirinya sendiri di dalam batin untuk mempertimbangkan, merenungkan, menganalisis, membuktikan sesuatu, menunjukkan alasan-alasan, menarik kesimpulan, meneliti suatu jalan pikiran, mencari berbagai hal yang berhubungan satu sama lain, mengapa atau untuk apa sesuatu terjadi, serta membahas suatu realitas." 17

Al-Qur'an menegaskan bahwa berpikir termasuk kegiatan bersyukur terhadap nikmat Allah, sedangkan mensyukuri nikmat Allah termasuk ketaatan yang bernilai ibadah. Jadi, berpikir itu pada hakikatnya adalah ibadah yang merupakan bagian dari amanat kemanusiaan. Dengan demikian, berpikir berarti pula menegakkan amanat tersebut. ${ }^{18}$ Dalam ayat-ayat al-Qur'an, Allah Swt. telah mendorong hamba-hambaNya agar merenungkan semua yang ada di alam jagad raya ini, agar dapat mengantar pada keyakinan tentang kemahakuasaan Allah Swt. Dalam membicarakn sifat-sifat Allah, sifat- sifat Nabi, sifat-sifat Malaikat, dan lainlain, para ulama tauhid hanya bersandar pada penalaran akal semata. Mereka membicarakan hal tersebut dalam konteks membuktikan kebenaran semua yang disampaikan oleh Nabi dengan akal. Jadi, menurut ulama tauhid, akal difungsikan sebagai sarana yang dapat membuktikan kebenaran syara', bukan sebagai dasar dalam menetapkan akidah-akidah dalam agama. Meski demikian, hasil penalaran akal yang sehat tidak akan keluar dan bertentangan dengan ajaran yang dibawa oleh syara'. ${ }^{19}$

Adapun kritis berkonotasi pentingnya atau sentralitas dari pemikiran yang mengarah pada pertanyaan isu atau masalah yang memprihatinkan. Kritis dalam konteks ini tidak berarti penolakan atau negatif. Ada yang positif dan berguna, misalnya merumuskan solusi yang terbaik untuk masalah pribadi yang kompleks, berunding dengan kelompok tentang tindakan apa yang harus diambil, atau menganalisis asumsi dan kualitas metode yang digunakan secara ilmiah dalam menguji suatu hipo penelitian. ${ }^{20}$ Sikap kritis tidaklah berarti suka menbantah dan mengritik, serba suka menentang dan menantang, melainkan berfikir dulu, mengidentifikasi duduknya perkara, menyelidiki dulu, dan tidak begitu saja menerima suatu pendapat atau penjelasan-penjelasan seakan-akan sudah pasti benar, atau tergesa-gesa mengambil kesimpulan yang berlaku umum. ${ }^{21}$

Terdapat beberapa kata kunci dalam memahami berpikir kritis dan kaitannya dengan kurikulum dan belajar mengajar. Pertama, sifat definisi berpikir kritis dan bagaimana hubungannya dengan apa yang dapat dikategorikan sebagai perspektif psikologis dan filosofis. Kedua, diidentifikasi terdapat beberapa

\footnotetext{
${ }^{16}$ Khalimi, Logika :Teori dan Aplikasi (Jakarta Selatan: GAung Persada Press, 2011), 41.

17 Widi Hidayat \& Tri Ratnawati, Filsafat Ilmu dan Logika Sains (Sidoarjo: Laros, 2013), 117.

18 Khalimi, Logika: Teori dan Aplikasi, 42.

19 Tim Aswaja NU Center PWNU Jawa Timur, Risalah Ahlussunnah wal-Jama'ah: Dari Pembiasaan Menuju Pemahaman dan Pembelaan Akidah-Amaliah NU (Surabaya: Khalista, 2015), 23.

20 Wowo Sunaryo Kuswana, Taksonomi Berpikir (Bandung: Remaja Rosdakarya, 2013), 20.

21 W. Poespoprodjo, Logika Ilmu Menalar (Bandung: Pustaka Grafika, 1999), 29.
} 
perbedaan dalam posisi filosofis yang berbeda, yang berhubungan dengan sifat berpikir dan kemampuan berpikir yang perlu diuraikan mengingat memberikan implikasi pada pembelajaran. Ketiga, adalah masalah penilaian dan cara berpikir kritis berkaitan dengan pengajaran dan kurikulum. Berprikir kritis menjelaskan tujuan, memeriksa asumsi, nilai-nilai, pikiran tersembunyi, mengevaluasi bukti, menyelesaikan tindakan, dan menilai kesimpulan. ${ }^{22}$ Berpikir kritis bisa terjadi kapan saja, seperti salah satu hakim memutuskan atau memecahkan masalah. Pada umumnya, setiap saat seseorang harus mencari tahu apa yang harus dipercaya atau apa yang harus dilakukan, dan melakukannya dengan cara yang wajar dan reflektif. Membaca, menulis, berbicara, dan mendengarkan bisa dilakukan dengan kritis atau tidak kritis. Berpikir kritis sangat penting untuk menjadi pembaca dan penulis dalam pemahaman substantif. Hal itu disajikan mulai dari yang paling umum sampai khusus. Oleh karena itu berpikir kritis merupakan cara mengambil keputusan dalam kehidupan.

Menurut konsensus para ahli, seorang individu atau kelompok yang terlibat dalam berpikir kritis kuat dicirikan oleh adanya bukti melalui observasi atau penilaian berdasarkan kriteria dengan metode atau teknik dan pengambilan keputusan yang relevan dengan konteksnya selain berlaku untuk merekonstruksi teori, juga dapat memahami masalah dan mengajukan pertanyaan. Berpikir kritis tidak hanya melibatkan logika, tetapi ada kesiapan kriteria intelektual yang luas seperti kejelasan, kredibilitas, akurasi, presisi, relevansi, kedalaman, keluasan makna, dan keseimbangan. ${ }^{23}$

Wujud nalar kritis santri Pondok Pesantren Gedangan ketika mengikuti forum bahts al-masâil dan di luar forum dapat dilihat di beberapa titik. Diantaranya adalah:

1. Kritis dalam menganalisa setiap pendapat dan temuan yang disampaikan peserta bahts al-masâil dan membutuhkan pola pikir yang mendalam dalam menanggapi jawaban mereka. Peserta yang demikian banyak secara kuantitas dengan kapasitas keilmuan berbeda, pola perpikir berbeda dan karakter pribadi berbeda akan memunculkan perdebatan alot dan panjang, sehingga benar-benar diperlukan kecerdasan intelektual yang tinggi untuk bisa menyelesaikan persoalan hukum yang dihadapi. Kalau santri lengah dalam memperhatikan setiap persepsi yang disampaikan oleh peserta bahts al-masâil, maka akurasi dalam memberi jawaban dan tanggapan akan berkurang atau bahkan akan salah. Karena setiap pendapat memiliki kaitan erat yang harus dipahami secara integral antara satu dengan yang lain.

Aspek ini memberi implikasi jelas terhadap tumbuh kembangnya berpikir kritis santri peserta bahts al-masâil di semua bidang dan di semua momen, baik dalam forum bahts al-masâil atau yang lain. Tidak mudah menerima satu pendapat sebagai rujukan tunggal yang paling benar dan tepat tapi welcome terhadap pendapat lain sebagai bahan seleksi dalam menentukan yang terbaik. Sangat lazim terjadi, satu pendapat yang didengarkan terlihat sempurna ketika itu tidak diadaptasikan dengan pendapat lain, sehingga melakukan koordinasi dengan banyak mitra mutlak dibutuhkan.

\footnotetext{
22 Kuswana, Taksonomi Berpikir. 19.

23 Ibid., 20.
} 
2. Kritis dalam menelaah referensi-referensi yang menjadi rujukan peserta bahts al-masâil. Karena kadang paparan yang disampaikan tidak sesuai dengan pemahaman teks yang sebenarnya. Kadang pula sekalipun benar paparannya tapi terdapat kelemahan yang fatal pada referensi tersebut, sehingga dinyatakan tidak mu'tabarah atau tidak bisa dipertanggungjawabkan, seperti karya di luar madzhab empat dan menyimpang dari konsensus ulama yang tidak dapat ditolerir.

Kritis dalam mengkaji legalitas referensi peserta bahts al-masâil menjadi sangat penting, mengingat maraknya oknom intelektual yang sangaja melakukan perang ideologi kotor untuk merusak pemikiran muslim termasuk santri melalui kitab-kitab yang dipalsukan, khususnya di bidang akidah ahlu alsunnah wa al-jamaah. Banyaknya koleksi kitab yang dipublikasikan di media cetak maupun online juga menjadi titik sulit dalam mengkroscek dan membedakan mu'tabarah tidaknya sebuah kitab. Ada beberapa aspek yang lazimnya menjadi tinjauan santri dalam menentukan benar tidaknya sebuah kitab. Diantaranya penulis atau pengarangnya dan isi yang dimuat. Integritas sebuah penulis kitab tidak menjadi jaminan orsinalitas isi kitab yang dimuat. Karena kadang meski penulisnya adalah ulama besar yang diyakini keafsahan ilmunya tapi isi kitab yang tertulis sengaja dirubah ke arah yang salah bahkan sesat menyesatkan oleh seorang oknum.

Karena itu, ketajaman mengamati setiap rujukan yang dijadikan istinbath sebuah hukum murni dibutuhkan dalam mengikuti bahts al-masâil. Hal ini memberi pengaruh yang signifikan terhadap terbentuknya sikap selektif terhadap referensi-referensi yang ditemukan di luar forum bahts al-masâil. Pengalaman banyak yang ditemukan di forum bahts al-masâil akan menjadi pelajaran penting dan warning yang berharga.

3. Kritis dalam memahami arah pertanyaan yang menjadi topik pembahasan dengan menganalisa kata demi kata yang berpotensi mengandung interpretasi makna yang berbeda. Dalam hal ini, moderator sebagai pimpinan bahts almasâil akan mempersilahkan peserta untuk bertanya dan menyampaikan persepsinya. Forum bahts al-masâil akan dilanjutkan kalau duduk masalah dari soal itu jelas dan dimengerti. Untuk memperjelas arah soal ini kadang tidak cukup pendapat dari peserta dan penanya tapi masih perlu mendatangkan seorang pakar yang ahli di bidang itu. Persoalan kekinian yang membahas tentang kedokteran, maka perlu mendatangkan tenaga kesehatan yang memang membidangi hal itu. Begitu juga persoalan lain. Masalah faktual yang terjadi di suatu daerah tertentu juga membutuhkan klarifikasi yang jelas dari objek tertentu yang mengalaminya. Perbedaan fakta di lapangan mempengaruhi perbedaan kedudukan hukum yang harus diambil.

Dalam hal ini, peserta tidak dapat mengeneralisir suatu kasus untuk semua persoalan. Karenanya, dari aspek ini mudah terbentuk konsep berpikir yang kritis sebelum menvonis status persoalan dan info yang diterima. Sikap tabayyun akan menjadi media sentral yang dimiliki untuk mengambil sebuah ketetapan dan keputusan. Pada gilirannya, mereka tidak akan tergolong orangorang yang termakan berita hoax, palsu dan jahat yang marak terjadi di media sosial, khususnya di tahun politik ini. 
4. Kritis dalam merespon keputusan yang diambil oleh mushahhih yang bertugas mengesahkan pendapat anggota bahts al-masâil. Peserta dituntut untuk memperhatikan secara cermat akurasi mushahhih dalam menilai jawabanjawaban peserta. Mencermati argumentasi yang digunakan mushahhih dalam menerima salah satu jawaban dan menolak jawaban yang lain atau dalam mengakomodir semua jawaban yang disampaikan peserta.

Hal ini legal dilakukan di forum bahts al-masâil, selama dengan cara yang santun dan memperhatikan kode etik yang benar dan baik. Tidak jarang apa yang disampaikan mushahhih masih ditentang oleh peserta, sehingga keputusan yang ditetapkan adalah kompilasi hukum yang disepakati bersama dan disahkan oleh mushahhih.

Budaya diskusi ini akan menciptakan daya nalar kritis terhadap santri dalam menanggapi sebuah pernyataan. Mereka tidak akan merasa sungkan untuk melakukan koreksi dan evaluasi kepada siapapun termasuk kepada yang lebih tua. Konsep yang dijadikan pijakan adalah meluruskan sebuah kesalahan adalah keharusan bagi praktisi pendidikan. Sebelum hukum itu dikonsumsi secara bebas oleh masyarakat, maka mengevaluasi adalah sesuatu yang perlu segera dilakukan.

5. Kritis terhadap tulisan hasil keputusan bahts al-masâil yang dilakukan sekretaris. Ada beberapa titik yang sering manjadi poin perhatian oleh peserta bahts al-masâil dalam mengkritisi itu. Diantaranya adalah sistematika penulisan dan ta'bir yang dimuat. Sistematika penulisan menjadi sorotan karena kadang susunan kata yang ditulis tidak selaras dengan keputusan bahts al-masâil yang diperoleh. Ragam istilah yang muncul dari beberapa peserta memang perlu kemampuan bagi sekretaris dalam menyusunnya secara tepat, sehingga mampu mengakomodir semua istilah yang digunakan dan pandangan yang muncul. Bagitu ta'bir yang dimuat perlu dikroscek secara intens. Karena ta'bir yang dijadikan dasar oleh peserta bahts al-masâil memang mesti dipilih sebagian oleh sekretaris, sehingga disitu peserta harus hadir menganalisa secara cermat agar ta'bir tersebut benar-benar mewakili ta'bir yang lain.

Dari sini akan memberi rekonstruksi pemikiran yang tajam terhadap santri dalam menelaah setiap karya tulis terkait dengan ketepatan bahasa yang digunakan, sistematika penulisan yang dimuat dan korelasi setiap kata.

\section{Faktor Pendukung Dan Hambatan Program Bahts Al-Masâil Di Pondok Pesantren Gedangan}

Program bahts al-masảil di Pondok Pesantren Gedangan memiliki sisi pendukung dan hambatan, sebagaimana berikut:

1. Faktor Pendukung

Ada beberapa kegiatan yang menjadi faktor pendukung jalannya bahts al-masảil di Pondok Pesantren Gedangan, yaitu:

a. Praktek pendalaman kitab kuning

Di tingkat MTs Pondok Pesantren Gedangan diadakan praktek pendalaman kitab kuning yang dijadikan kurikulum resmi dalam madrasah. Sejak kelas 1 MTs sampai III MTs santri dibimbing secara bertahap, mulai dari pengulangan ilmu dasar tentang Nahwu-Sharraf, peraktek langsung membaca kitab, memahami kandungan isinya dengan cara menterjemahkan 
sampai pada teori terakhir yaitu menarik sebuah kesimpulan dari ibarat kitab yang dibaca. Karena itu, kurikulum madrasah juga menjadi bagian penting dalam mensukseskan proses bahts al-masảil.

Ketika pendalaman Nahwu-Sharraf sudah tuntas di tingkat MTs, maka mengembangkan bahts al-masảil di tingkat MA merupakan sesuatu yang realistis karena santri bisa fokus melakukan diskusi.

b. Banyaknya referensi kitab kuning

Pondok Pesantren Gedangan merupakan lembaga pendidikan Islam yang banyak menerapkan kurikulum kitab kuning, baik di madrasah, kajian kitab dan kegiatan ekstra kurikuler. Dengan demikian, santri sudah familiar dengan referensi yang bertulis bahasa Arab yang netabene merupakan sumber rujukan para santri dalam melakukan bahts al-masảil.

c. Program bahts al-masảil yang berkelanjutan

Program bahts al-masảil di Pondok Pesantren Gedangan dilaksanakan di 4 jenjang dengan sistem berkelanjutan. Sistem ini menjadi bagian sentral dalam memproduksi santri kompeten di tingkat MA. Sejak tingkat MI dan MTs dalam kurun waktu 9 tahun mereka aktif melakukan diskusi, belajar menyampaikan pendapat, menganalisa setiap persepsi yang berbeda, dipertajam dengan kajian nahwa-sharraf, sehingga di tingkat MA mereka bisa mengaktualisasikan kemampuannya dengan baik.

2. Faktor Hambatan

Ada beberapa hal yang menjadi faktor hambatan jalannya bahts almasảil di Pondok Pesantren Gedangan, yaitu:

a. Banyaknya kegiatan di Pondok Pesantren Gedangan

Di Pondok Pesantren Gedangan banyak kegiatan wajib yang harus dilaksanakan oleh santri. Selain ragam kegiatan itu membutuhkan waktu untuk diikuti, santri juga harus menyelesaikan PR (pekerjaan rumah) dari semua kegiatan yang dilaksanakan. Karenanya, santri tidak bisa memfokuskan waktunya untuk mempersiapkan materi bahts al-masảil. Butuh kesiapan santri untuk menahan capek dan lelah dan kelehaian dalam menjaga managemen waktu demi tercapainya kualitas bahts al-masảil yang baik.

b. Keharusan menjaga etika dalam berdiskusi

Menjaga etika berbicara dan berpendapat tetap harus menjadi perhatian utama oleh santri ketika mengikuti bahts al-masảil khususnya dalam mengkritisi pendapat yang lebih tua, seperti setingkat putra kiai atau gurunya sendiri yang bertindak sebagai mushahhih. Secara esensial, ini merupakan hal baik tapi di sisi lain dapat berpengaruh terhadap sikap kurang tegas dan kurang keras terhadap silang pendapat yang terjadi. 


\section{Kesimpulan}

Dari paparan di atas dapat disimpulkan bahwa program bahts al-masâil di Pondok Pesantren Gedangan dilaksanakan di 4 jenjang, yaitu Madrasah Ibtidaiyah (MI), Madrasah Tsanawiyah (MTs), Madrasah Aliyah (MA) dan Guru. Setiap jenjang punya prosedur dan mekanisme khusus yang didesain secara berkelanjutan, sehingga di bahts al-masâil tingkat MA para santri mampu terampil sebagai peserta yang punya nalar kritis.

Adapun implikasi bahts al-masâil terhadap nalar kritis santri Pondok Pesantren Gedangan adalah: Pertama, santri kritis dalam menganalisa setiap pendapat dan temuan yang disampaikan peserta bahts al-masâil, sehingga tercipta siklus berpikir tidak mudah menerima satu pendapat sebagai rujukan tunggal yang paling benar tapi welcome terhadap pendapat lain sebagai bahan pertimbangan dalam menentukan yang terbaik. Kedua, santri kritis dalam menelaah referensireferensi yang menjadi rujukan peserta bahts al-masâil, sehingga berpengaruh terhadap terbentuknya sikap selektif terhadap referensi-referensi yang ditemukan di luar forum bahts al-masâil. Ketiga, santri kritis dalam memahami arah pertanyaan yang menjadi topik pembahasan. Dari aspek ini mudah terbentuk konsep berpikir yang kritis sebelum menvonis status persoalan. Keempat, santri kritis dalam merespon keputusan yang diambil mushahhih. Budaya diskusi ini akan menciptakan sikap berani dan tidak sungkan melakukan koreksi dan evaluasi kepada siapapun termasuk kepada yang lebih tua dengan cara yang sopan. Kelima, santri kritis terhadap tulisan hasil keputusan bahts al-masâil yang dilakukan sekretaris.

\section{Daftar Pustaka}

Bahri Ghazali, Pesantren Berwawasan Lingkungan (Jakarta: CV. Prasasti, 2002)

Basrowi \& Suwandi, Memahami Penelitian Kualitatif (Jakarta: Rineka Cipta, 2008)

Kementerian Agama, Fikih Pendekatan Saintifik Kurikulum 2013 Madrasah Aliyah Kelas X (Jakarta: Kementerian Agama, 2015)

Kementerian Agama, Fikih Pendekatan Saintifik Kurikulum 2013 Madrasah Aliyah Kelas XI (Jakarta: Kementerian Agama, 2015)

Khalimi, Logika :Teori dan Aplikasi (Jakarta Selatan: GAung Persada Press, 2011)

M. Ridlwan Qoyyum Sa'id, Rahasia Sukses Fuqoha (Kediri :Mitra Gayatri, 2006)

Mohammad Tidjani Djauhari, Masa Depan Pesantren, Agenda yang Belum Terselesaikan (Jakarta: Taj Publishing, 2008)

Saifullah Ma'shum dalam Ahmad Zahro, Lanjah Bahtsul Masail 1926-1999, Tradisi Intelektual NU (Yogyakarta: PT. LKiS, 2004)

Sukardi, Metodologi Penelitian Pendidikan (Jakarta: Bumi Aksara, 2013)

Syahraini Tambak, 6 Metode Komunikatif Pendidikan Agama Islam (Yogyakarta: Graha Ilmu, 2014)

Tim Aswaja NU Center PWNU Jawa Timur, Risalah Ahlussunnah wal-Jama'ah: Dari Pembiasaan Menuju Pemahaman dan Pembelaan Akidah-Amaliah NU (Surabaya: Khalista, 2015)

Tim Kajian Fikih Pondok Pesantren Sidogiri, Santri Salaf Menjawab 2 (Pasuruan: Pustaka Sidogiri Pondok Pesantren Sidogiri, 1437 H.) 
Tim Lajnah Ta'lif wa al-Nasyr, Ahkamul Fuqaha, Solusi Problematika Aktual Hukum Islam, Keputusan Muktamar, Munas, dan Konbes NU (1926-2010) (Surabaya: Khalizta, 2011)

W. Poespoprodjo, Logika Ilmu Menalar (Bandung: Pustaka Grafika, 1999)

Widi Hidayat \& Tri Ratnawati, Filsafat Ilmu dan Logika Sains (Sidoarjo: Laros, 2013)

Wowo Sunaryo Kuswana, Taksonomi Berpikir (Bandung: Remaja Rosdakarya , 2013) 